\title{
Creating an Entrepreneurial Culture Among Students Through Entrepreneurship Development Programmes (EDP)
}

\author{
Natanya Meyer \\ Faculty of Economic Sciences and Information Technology, School of Economic Sciences \\ North-West University, South Africa \\ Email: natanya.meyer@nwu.ac.za
}

Doi:10.5901/mjss.2014.v5n13p281

\begin{abstract}
Entrepreneurship is the cornerstone of economic growth and financial independence. This paper reports on the perception of students regarding entrepreneurship. Unemployment, especially for the youth, is a reality not only in South Africa but in many other countries globally. Creating a culture and awareness of students to become entrepreneurs is believed to be one solution to reduce unemployment. Various literature sources were examined during the compilation of a questionnaire, comprising 53 questions regarding issues relating to entrepreneurship, unemployment and job possibilities. Approximately 400 students from the Faculty of Economic Sciences and IT at the Vaal campus of North West University in Gauteng province, South Africa formed part of the survey and 293 completed questionnaires were received back. The questionnaire was pre-tested and piloted before the main survey. Data were analysed using z-tests and p-tests, and indicate that the implementation of entrepreneurship development programmes (EDPs) for students would be well supported. The students have a realistic view of the risk of unemployment and show a favourable attitude to entrepreneurship, which is seen as a possible safeguard against unemployment. It is believed that by introducing EDPs to students as early as their first year of study will create a culture to become self-employed. This could, in turn, improve economic development and help reduce youth unemployment in developing countries.
\end{abstract}

Keywords: Entrepreneurship Development Programmes (EDPs), entrepreneurship, unemployment, students, South Africa

\section{Introduction}

An old philosophy regarding entrepreneurship states that entrepreneurs are born, and not created. This statement could be partially correct; however, with proper training and the creation of an entrepreneurial culture, entrepreneurship development programmes (EDPs) can create and train entrepreneurs. Entrepreneurship education does not only build and shape better and stronger entrepreneurs, it also develops attitudes, creates values and motivation and helps students and people participating in these programmes to acquire skills they can use in any job or task in which they might be involved (Bhat \& Khan, 2014).

Job creation has been a global challenge for many years, including in South Africa (Meyer, 2014a). The unemployment rates are high in countries such as Spain (25\%), Greece (24\%), and Lesotho (25\%), and relatively high in countries such as Italy (11\%), Portugal (16\%), and Ireland (15\%) (CIA, 2013). A growing global problem is that of youth unemployment rates, which affect those between the ages of 15 and 24 in particular. Compared to national unemployment rates, the results are quite shocking. According to the 2012 World Fact Book, Spain has a youth unemployment rate of 46 percent, Greece 44 percent, Portugal 30 percent, Ireland 29.4 percent, Italy 29.1 percent and rising to 35 percent in 2012 (CIA, 2012). Unemployment is part of the reality of many South Africans, with the official unemployment rate of the country at 25.2 percent, and a youth unemployment rate of more than 50 percent (StatsSA, 2013a). Globally, the average unemployment rate is approximately 9.2 percent (CIA, 2013), ranking South Africa's rate $169^{\text {th }}$ out of 202 countries. This looming reality creates fear among young graduates, as they too could become a part of these statistics. Due to this alarming fact, it should be a component of the aim of any university to empower graduates by fostering entrepreneurship through education.

There are many causes of youth unemployment, but some of the main causes are rural-urban migration, they make up a large proportion of the population, low education levels in rural areas, poverty, corruption, strict labour laws, economic conditions and the influx of migrants.

Rural-urban migration can be explained by means of push-pull factors. Many young people move from rural areas into more formal and urbanised areas looking for better living conditions resulting in a huge influx, and in many cases, creating an oversupply of employment in these urbanised areas (Stutz \& Warf, 2012).

In particular, the people who fall within the youth category of between 15 and 24 constitute to a large portion of 
the population. In the mid-year report issued by Statistics South Africa (StatsSA, 2011) this category consisted of 10 075823 of the total South African population of 50586 757. This is equivalent to 20 percent of the country's population. During 2013, this figure rose slightly to 10203329 people between the ages of 15 and 24, which is equivalent to 19 percent of the population during that year, as the total population grew by approximately 2500000 people. (StatsSA, 2013b).

Low education levels in rural areas can be considered another factor, as many rural schools lack proper teachers and resources. This adds pressure on students who, in many cases, fall behind. These students will seldom have the skills and knowledge to become an entrepreneurial business owner. In a recent study by the Southern and Eastern Africa Consortium for Monitoring Educational Quality (SACMEQ) it was found that South Africa achieved a low ranking of $10^{\text {th }}$ out of 15 countries in Africa regarding reading, mathematics and health (Wilkinson, 2014).

Poverty is still a global problem, and the reduction thereof is one of the main priorities of the Millennium Development Goals (MDG) as declared by the United Nations in 2000 (UN, 2003). A total of 2.6 billion people, or approximately 40 percent of the global population, live below the global poverty line of US\$2.00/day, and most of these people live in poverty and lack services and basic needs (Meyer, 2014b). Not having basic needs and services, and being poor, could definitely have an impact on employment rates, as it impacts on the availability of resources in order to find a job or start a business. Poverty also influences education levels negatively. Taylor, Van der Berg and Burger (2014) point out that socio-economic factors such as poverty have a negative impact on education, and in turn can lead to the loss of employment and income.

Corruption can also be blamed as a possible cause for unemployment. In countries such as Nigeria and South Africa, where corruption levels are very high, it is believed that money aimed at facilitating entrepreneurship and other small business development is wrongfully stolen from these projects, affecting the outcome negatively (Uddin \& Uddin, 2013; Odusegun, 2014).

The International Monetary Fund (IMF) criticised South Africa regarding the country's strict labour regulations, claiming that these laws intensify unemployment and hamper economic growth (Anderson, 2005). When strong regulation and strict labour laws are in place within a country, companies are likely to employ a minimum number of workers. There are various reasons for this, which include the implementation of minimum wages as many unemployed people would have been prepared to work for a lower wage but are prohibited by labour laws, and the tedious dismissal procedure, because if a company wishes to dismiss an employee, the process is so time consuming and costly that they would rather not appoint someone in that position.

Another cause for unemployment is economic conditions. Bad economic conditions lead to small businesses closing down and larger companies not hiring any, or only a very few, new staff members. The influx of migrant workers from neighbouring countries has an adverse effect on unemployment rates. These migrant workers are often willing to work for a much lower wage than the citizens of the country are, and this could mean that companies prefer employing these migrants, rather than the currently unemployed citizens.

Naude, Gries, Wood and Meintjies (2008) highlight the importance of entrepreneurs as a channel for spillovers associated with agglomerations and indicated that entrepreneurship is an important determinant of regional economic performance. Entrepreneurship can impact the economic performance at three different levels, namely individual, firm and societal levels (Wennekers, Uhulaner \& Thurik, 2002). On an individual level, entrepreneurs affect their own economic performance as they earn a salary, which they use to support themselves and their families. On a firm level, the entrepreneurial businesses pay taxes and spend money on production and operating costs. On a societal level, the entrepreneurs employ people who would have been unemployed. These employed people earn a salary to spend, and pay taxes, impacting positively once again on the economic performance of a country or region.

The role of entrepreneurship as a contributing factor for economic development has many times before been highlighted in the literature (Awashti \& Sebastian, 1996; Athayde, 2012). Entrepreneurship should be emphasised even more in developing countries such as South Africa, were unemployment is an ever-increasing problem. Entrepreneurship is also seen as part of a knowledge economy, meaning that entrepreneurship education can be extremely beneficial for the creation of new knowledge-based, graduate-led ventures (Kirby \& Humayun, 2013).

Entrepreneurship offers opportunities for people to achieve financial freedom and independence (Raguž \& Matić, 2011). The role of entrepreneurship in local communities and societies has increased in recent years and there is a need to include entrepreneurship education as a topic within universities (Venesaar, Ling \& Voolaid, 2011). According to Ekpoh and Edet (2011), there is a positive link between entrepreneurship education and entrepreneurial attitudes, and entrepreneurship education could improve the understanding and awareness of entrepreneurial abilities among students (Bagheri \& Pihie, 2011). Therefore, it could have positive impacts if entrepreneurial educational courses are incorporated as part of university student programmes (Tkachev \& Kolvereid, 1999). This can be achieved by introducing EDPs, also 
known as business promotion programmes or young enterprises programs (this type of programme might have different names in different countries or institutions), as early as during the first year of a student's degree. An EDP can be defined as a learning programme with the main objectives being the development and enhancement of an entrepreneurial culture or mindset, and to train enterprise creators (Allan Grey Orbis Foundation, 2013; Chowdhary \& Prakash, 2010).

The concept of an EDP is not new and was experimented with in the late sixties. These EDPs aimed at training selected entrepreneur candidates on how to set up a small business, how to manage it, and how to make profit. These early EPDs were established in Gujarat, a state on the north-west coast of India. It was a joint initiative by the Gujarat Investment Corporation and other state agencies (Awashti \& Sebastian, 1996). Other successful EDPs, or business promotion programmes, were initialised in Germany, France and Great Britain. The governments of the respective countries instituted the programmes in order to reduce the unemployment rates and increase self-employment simultaneously. However, they were not aimed at university students, but at the unemployed population (Remeikienè \& Startienè, 2013).

The benefits of a successful EDP far outweigh the challenges. Some of the benefits include 1) positively affecting the employment rate within developing countries, 2) reducing the gender, age group as well as wage differences in some of the labour markets, 3) human capital increase in the form of knowledge, qualification, education, working abilities and experience, and 4) establishing of useful business contacts and other successful entrepreneurs (Remeikienè \& Startienè, 2013).

Although Awashti and Sebastian (1996) are of opinion that the benefits of an EDP will outweigh the challenges, the reality of various problems pertaining to EDPs still exists. Some of these challenges include 1) selections of the right candidates for the programme, 2) lack of seriousness and commitment from the organisations conducting the EDP, 3) lack of motivation from the training authorities to the participating candidates within the programme, 4) a non-conductive environment, 5) the non-participative attitudes of supporting role players such as established self-employed business owners and larger corporations (Chowdhary \& Prakash, 2010), 6) monitoring of the EDP to ascertain the success rate, 7) following up on the success rate of the EDP after completion (Awashti \& Sebastian, 1996), and 8) funding the EDP.

An EDP should have very clear objectives from the start to create a measurable expectancy from the presenter or promoter of the programme as well as the trainee. Not all EDPs will have the same objectives; however, some goals should form the basis of a well planned EDP. These include 1) to increase the supply of entrepreneurs who start new businesses, 2) to reduce to rate of unemployment by creating self-employment as well as employment of others, 3) promoting first generation entrepreneurs by diversifying the base of enterprise ownership, 4) improving the quality of entrepreneurs (Awashti \& Sebastian, 1996), 5) stimulation and identification of entrepreneurial talent, skills and drive, and 6) devising attitudes towards change (Garavan \& O'Cinneide, 1994). Support for the students who completed the EDP from the university or institution is also very important. This can be in the form of incubation programmes assisting these students with their start-up ventures.

The aim of this study was to determine the students' perceptions towards unemployment, motivation to become self-employed, and attitude towards the possibility of starting an entrepreneurship development programme on the campus as an addition to their degree or course they have enrolled for.

\section{Methodology}

\subsection{Sample}

The sample for this study comprised first-, second- , third-year and postgraduate students from a traditional university, namely the Vaal campus of the North West University, situated in Gauteng province, South Africa. This campus has already created a favourable attitude towards creating entrepreneurship awareness among students and local businesses with the introduction of the Enterprise Development Centre (EDC) during 2011; further investigation into the possibility of offering students EDP options are currently being explored.

\subsection{Sampling method}

A non-probability convenience sample of 400 students was drawn from the campus, which was limited to students from the Faculty of Economic Sciences and IT, as the study aimed at determining their specific attitudes towards the implementation of an EDP. Lecturers in the faculty were requested to distribute the questionnaire in their classes. All participants completed the questionnaire voluntary and no incentives were provided to encourage participation. Full confidentiality was assured to the participants as no names or contact details were disclosed. 


\subsection{Research instrument}

A descriptive research design, using a survey self-administered questionnaire, was employed for the study. Following a review of the literature, items were generated to determine students' perceptions towards finding a job, entrepreneurship and unemployment. The questionnaire included a section requesting demographical information. The questionnaire was pre-tested using the debriefing approach on three students to ascertain if all items were understood in the manner that was intended (Synodinos, 2003). Thereafter, it was pilot-tested on a sample of 35 students registered at the same university. These students did not form part of the final study. The 53 scaled responses were measured by using a sixpoint Likert scale, which ranged from strongly disagree (1) to strongly agree (6). The Likert scale was selected due to its popularity and as it is one of the most commonly used non-comparative scaling techniques (Bertram, 2006).

\section{Results and Discussion}

During data collection, 400 questionnaires were distributed over a timeframe of a week. Of the 400 questionnaires distributed, 293 completed questionnaires were returned, which equates to a 73.25 percent response rate. Respondents were mainly female (56.2\%), and predominantly between the ages of 19 and 21. Even though most of the respondents indicated that they were from Gauteng $(69.6 \%)$, all nine provinces were represented. The sample comprised predominantly African/black students (55.3\%) and white students (39.2\%). The majority of the participants were in their second (36.6\%) and first year (34.6\%) of study. A few other important questions were asked in this section and they included the type of living environment whilst growing up, parent self-employment, and awareness of EDPs. Of the respondents, 35.2 percent indicated that at least one of their parents was self-employed. Concerning living environment, 18.2 percent indicated that they grew up in a rural or informal settlement, and 81.8 percent indicated that they grew up in an urban or formal areas. Interestingly, 28.5 percent reported that they had never heard of an EDP. Table 1 outlines a description of the sample.

Table 1: Sample description

\begin{tabular}{|c|c|c|c|c|c|c|c|c|c|}
\hline $\begin{array}{l}\text { Age } \\
\text { (Yr) }\end{array}$ & $(\%)$ & Gender & $(\%)$ & Year of study & $(\%)$ & Home Province & $(\%)$ & Race & $(\%)$ \\
\hline 18 & 3.1 & Female & 56.2 & 1 & 34.6 & Eastern Cape & 2.4 & Coloured & 3.1 \\
\hline 19 & 25 & Male & 43.8 & 2 & 36.6 & Free State & 10.4 & Indian/Asian & 2.4 \\
\hline 20 & 26 & & & 3 & 23.6 & Gauteng & 69.6 & White & 39.2 \\
\hline 21 & 24.7 & & & Post-graduate & 5.1 & KwaZulu- Natal & 1.7 & African/ Black & 55.3 \\
\hline 22 & 10.6 & & & & & Mpumalanga & 5.9 & & \\
\hline 23 & 6.5 & & & & & North West & 2.8 & & \\
\hline 24 & 2.1 & & & & & Northern Cape & 6.2 & & \\
\hline \multirow[t]{2}{*}{$24+$} & 2.1 & & & & & Western Cape & 0 & & \\
\hline & & & & & & Limpopo & 1 & & \\
\hline
\end{tabular}

The paper reports on 12 mutually exclusive items that formed part of the wider study. Table 2 presents the descriptive statistics computed from the collected data.

Table 2: Descriptive statistics

\begin{tabular}{lcccc}
\hline Item & $\begin{array}{c}\text { Mean } \\
\mathbf{N = 2 9 3}\end{array}$ & $\begin{array}{c}\text { Standard } \\
\text { deviation }\end{array}$ & Skewness Kurtosis \\
\hline $\begin{array}{l}\text { As I continue with my university education I become scared of finishing my degree } \\
\text { as I do not know what to expect after university }\end{array}$ & 3.8 & 1.6 & -0.3 & -1.0 \\
As I continue with my university education I realise I might not find that perfect job I & 4.1 & 1.5 & -0.5 & -0.6 \\
was hoping for & 4.3 & 1.6 & -0.6 & -0.7 \\
My career intentions after completing my degree is to become an entrepreneur & 5.4 & 1.2 & -2.4 & 5.1 \\
I believe that unemployment is a problem in South Africa & & -0.6 & -0.4 \\
I believe that I might at some stage in my life be unemployed after completing my & 4.0 & 1.5 & -0.5 \\
studies & & & -1.4 & 2.0 \\
I believe that becoming an entrepreneur and starting my own business could & 5.0 & 1.1 & -0.8 & 0.1 \\
possible decrease the unemployment rate in South Africa & & &
\end{tabular}




\begin{tabular}{lllll}
$\begin{array}{l}\text { During completion of my degree I obtained enough theoretical training to start my } \\
\text { own business }\end{array}$ & 4.3 & 1.4 & -0.8 & -0.1 \\
$\begin{array}{l}\text { During completion of my degree I would have liked more practical assistance and } \\
\text { guidance on how to start my own business }\end{array}$ & 4.8 & 1.2 & -1.1 & 0.8 \\
$\begin{array}{l}\text { During completion of my degree I would have liked additional training or workshops } \\
\text { on how to successfully become an entrepreneur (business owner) }\end{array}$ & 4.8 & 1.2 & -1.1 & 1.0 \\
$\begin{array}{l}\text { During completion of my degree I would have liked to be part of an Entrepreneur } \\
\text { Development Programme if it was presented on campus }\end{array}$ & 4.7 & 1.3 & -1.0 & 0.7 \\
The idea of starting my own business came from fear of not finding a job & 3.7 & 1.7 & -0.2 & -1.2 \\
\hline
\end{tabular}

As is evident from Table 2, means above three (indicating agreement) were computed on all of the items. With the current youth unemployment rate in South Africa at around 50 percent, it is not surprising that the two highest means reported from the survey was regarding unemployment. The students general perception was that by improving entrepreneurship, the unemployment rate could decrease. Students generally would have liked assistance that is more practical, additional workshops, training regarding entrepreneurship, as well as to participate in an EDP while completing their degree.

In order to determine whether these means are statistically significant, a one-tailed z-test was performed, whereby the expected mean was set at $X>3$ and the significance level at $a=0.05$. Table 3 reports on the calculated $z$-values and $p$ values.

Table 3: Student perceptions towards entrepreneurship

\begin{tabular}{|c|c|c|c|c|c|}
\hline Construct/ltem & $\begin{array}{c}\text { Mean } \\
\mathrm{N}=293\end{array}$ & Standard deviation & Standard error & z-value & $\mathrm{p}$-value \\
\hline $\begin{array}{l}\text { As I continue with my university education I become scared of } \\
\text { finishing my degree as I do not know what to expect after university }\end{array}$ & 3.8 & 1.6 & 0.09 & 147.4 & $0.000^{*}$ \\
\hline $\begin{array}{l}\text { As I continue with my university education I realise I might not find } \\
\text { that perfect job I was hoping for }\end{array}$ & 4.1 & 1.5 & 0.08 & 221.3 & $0.000^{*}$ \\
\hline $\begin{array}{l}\text { My career intentions after completing my degree is to become an } \\
\text { entrepreneur }\end{array}$ & 4.3 & 1.6 & 0.09 & 245.4 & $0.000^{*}$ \\
\hline I believe that unemployment is a problem in South Africa & 5.4 & 1.2 & 0.07 & 554.3 & $0.000^{*}$ \\
\hline $\begin{array}{l}\text { I believe that I might at some stage in my life be unemployed after } \\
\text { completing my studies }\end{array}$ & 4.0 & 1.5 & 0.08 & 203.0 & $0.000^{*}$ \\
\hline $\begin{array}{l}\text { I believe that becoming an entrepreneur and starting my own } \\
\text { business could possible decrease the unemployment rate in South } \\
\text { Africa }\end{array}$ & 5.0 & 1.1 & 0.06 & 510.0 & $0.000^{*}$ \\
\hline $\begin{array}{l}\text { If I do not find a job after completing my degree I will try to start my } \\
\text { own business and create my own employment }\end{array}$ & 4.5 & 1.3 & 0.07 & 329.4 & $0.000^{*}$ \\
\hline $\begin{array}{l}\text { During completion of my degree I obtained enough theoretical } \\
\text { training to start my own business }\end{array}$ & 4.3 & 1.4 & 0.08 & 281.7 & $0.000^{*}$ \\
\hline $\begin{array}{l}\text { During completion of my degree I would have liked more practical } \\
\text { assistance and guidance on how to start my own business }\end{array}$ & 4.8 & 1.2 & 0.07 & 416.6 & $0.000^{*}$ \\
\hline $\begin{array}{l}\text { During completion of my degree I would have liked additional training } \\
\text { or workshops on how to successfully become an entrepreneur } \\
\text { (business owner) }\end{array}$ & 4.8 & 1.2 & 0.74 & 415.2 & $0.000^{*}$ \\
\hline $\begin{array}{l}\text { During completion of my degree I would have liked to be part of an } \\
\text { Entrepreneur Development Programme if it was presented on } \\
\text { campus }\end{array}$ & 4.7 & 1.3 & 0.07 & 393.4 & $0.000^{*}$ \\
\hline $\begin{array}{l}\text { The idea of starting my own business came from fear of not finding a } \\
\text { job }\end{array}$ & 3.7 & 1.7 & 0.10 & 126.4 & $0.000^{*}$ \\
\hline
\end{tabular}

As can be seen from Table 3, the computed mean responses to each of the items are statistically significant $(p<0.05)$. This infers that the respondents realise that they might face unemployment or not find a job one day $(p=0.000<0.05)$, would like to become self-employed and form part of an $\operatorname{EDP}(p=0.000<0.05)$, believe that unemployment is a problem in South Africa $(p=0.000<0.05)$, and would have liked more practical experience on how to become entrepreneurs during the duration of their degree $(p=0.000<0.05)$. These findings also indicate that students have a positive attitude towards entrepreneurship $(p=0.000<0.05)$.

In theory, entrepreneurship programmes should improve the output of sustainable and successful business 
owners, however, the success of these programmes is difficult to measure. Another possible problem is the attitudes of students towards these programmes when they are introduced into an existing university degree or programme. Traditional EDPs are presented normally as a short course or programme to individuals entering into the programme. As seen in the EDPs implemented in India, Germany, France and Great Britain, these programmes were mostly initiated by the government or by private institutions. Similar programmes presented in South Africa include the Community Entrepreneurship Development Programme (CEDP), managed by the Crossover Transformation Group (2013). Their main objective is to provide mentorship and assistance to people living in previously disadvantage areas regarding business development. The Western Cape government has three initiatives linked to the National Development Plan. These include 1) the Enterprise Dynamics Programme for grade 1 to 12 students, 2) Mini-Enterprise Programme for senior secondary school learners, and 3) the Business Establishment and Sustainability Programme (BESP) aimed at providing training for people with no or limited formal education. Private institutions, in the form of internships, do other forms of training programmes. As can be seen from the listed programmes, they are not aimed at providing additional and practical training for graduates during the completion of their degrees.

The findings of this study suggest that implementing an EDP for students registered at the University's Faculty of Economic Sciences and IT would be supported well. The evidence in the sample indicates that students have a realistic view of the risk of unemployment and have a favourable attitude to entrepreneurship in general, as well as a possible safeguard against unemployment. In order to be of value, such a programme should focus on providing practical entrepreneurial skills that will equip graduates to compete effectively in day-to-day business. As indicated by Ligthelm (2010), support should also be provided for business start-ups after they have established a business, as many of them will not remain sustainable without assistance during the first few years of their existence. This can be done though advice centres within the incubators situated on the university campus where the initial EDPs were presented. Entrepreneurship development should be a fundamental topic raised not only at government level, but also at primary, secondary and tertiary level. Fostering and creating a culture for entrepreneurship in the early stages of development and learning will contribute to the successful creation of self-employed ventures, which in turn could reduce the unemployment and poverty rate to an extent.

A study done in Nigeria also indicated that youth unemployment is a huge problem and the every year thousands of graduates leave universities and remain unemployed for long periods of time. In their study, the authors indicate how many of these youth then turn to cybercrime and other forms of intelligent crimes. If they could have received entrepreneurial training or had assistance, they could have converted their knowledge into a feasible IT business instead of a criminal act (Uddin \& Uddin, 2013). They further state that all levels of government should strive to encourage the youth to think rationally towards job creation. Another study done in Nigeria found that unemployment is related negatively to entrepreneurship development, and that the higher the unemployment rate, the lower the level of entrepreneurial development is within that country. Thus, increasing the entrepreneurial support and activities could decrease the unemployment rate (Oladele, Akeke \& Oladunjoye, 2011). Solomon, Duffy \& Tarabishy (2002) also noted these finding.

\section{Recommendation and Conclusion}

Unemployment is a worldwide problem, but with proper strategies and planning, including promotion of entrepreneurship development training, it could possibly be reduced. A major problem exists with youth unemployment in many countries. Therefore, it of the utmost importance to implement any strategy or programme that may provide a foundation for young graduates to utilise the information they were taught during the completion of their degrees, by means of own venture start-up, in the likely event of them not finding employment. The following is recommended:

- Government should create an enabling environment for entrepreneurs. This can be done by implementing EDPs and similar programmes as a compulsory module or course during primary, secondary and university level.

- Local businesses should become involved with these projects, especially at university level, where they can assist in training and practical workshops.

- Internship programmes should be created by larger business who can then appoint graduates from these programmes.

- Relaxation of rules and regulations regarding the process of starting a business as strict laws and timeconsuming processes makes the task of starting a business very difficult.

- Government needs to implement strategies that promote small business start-ups, especially for the youth section of the population. 
- Mentorship programmes needs to be created by business and other institutions.

- Business incubators need to be more active in their creation of entrepreneurs and assisting them with their possible start-ups.

- Support to new business should be continued for a period after starting up, as many businesses fail within their first years of operation.

- Technical and practical skills also need to be developed within these programmes.

Implementing all or some of these recommendations within South Africa could have a huge impact on the current youth employment rate. Based on the outcome of this study and the positive attitude of the students towards entrepreneurship and self-employment it is believed that a well-managed and well-designed EDP would be successful and accepted among students registered at the Faculty of Economic Sciences and IT at the North West University (Vaal Campus).

\section{References}

Allan Grey Orbis Foundation. (2013). Investing in a long term legacy of greatness. Retrieved from http://allangreyorbis.org.

Anderson, S.E. (2005). IMF criticises 'strict' labour regulations [Online] Available: http:// www .skillsportal.co.za/page/features/496293IMF-criticises-strict-labour-regulations.

Athayde, R. (2012). The impact of enterprise education on attitudes to enterprise in young people: an evaluation study. Education and Training, 54(8/9), 709-725.

Awashti, D \& Sebastian, J. (1996). Evaluation of entrepreneurship development programmes. New Delhi: Sage Publications.

Bagheri, A. and Pihie, Z.A.L. (2011). On becoming an entrepreneurial leader: a focus on the impacts of university entrepreneurship programs. American Journal of Applied Sciences, 8(9), 884-892.

Bertram, D. (2006). Likert Scales. CPSC 681 - Topic Report. . [Online] Available: http://poincare.matf.bg.ac.rs/ kristina/topic-danelikert.pdf. (17 November 2013).

Bhat, S.A. \& Khan, R.A. (2014). Entrepreneurship awareness programmes (EAPs) impact on the promotion of youth entrepreneurship. Radix International Journal of Research in Social Sciences, 3(1), 1-12.

Chowdhary, N. \& Prakash, M. (2010). Entrepreneurship development programme or process. IIMS Journal of Management Science, $1(1), 46-59$.

CIA World Fact Book. (2012). The world fact book. Retrieved from http://cia.gov.

CIA World Fact Book. (2013). The world fact book. . [Online] Available: http://cia.gov/library/publications/the-world-factbook/fields/2129.html. (17 November 201).

Crossover Transformation Group. (2013). Community Entrepreneurship Development Programme. . [Online] Available: http://crossovertransformation.co.za.(15 May 2014).

Ekpoh, U.I. and Edet, A.O. (2011). Entrepreneurship education and career intentions of tertiary education students in Akwa Ibom and Cross River States, Nigeria. International Education Studies, 4(1), 172-177.

Garavan, T.N. and O'Cinneide, B. (1994). Entrepreneurship education and training programmes: a review and evaluation - Part 1. Journal of European Industrial Training, 18(8), 3-12.

Kirby, D.A. \& Humayun, H. (2013). Outcome of entrepreneurship education programme: an Empirical study in Egypt. International Journal of Management, 30(3), 23-35.

Ligthelm, A.A. (2010). Entrepreneurship and small business sustainability. Southern African Business Review, 14(3), 131-153.

Meyer, D.F. (2014a). Job creation, a mission impossible? The South African case. Mediterranean Journal for Social Sciences, 5(11), 6577.

Meyer, D.F. (2014b). LED, challenges and solutions: The case of the Northern Free State region. Mediterranean Journal for Social Sciences, 5(11), 580-590.

Naudè, W., Gries, T., Wood, E. \& Meintjies, A. (2008). Regional determinants of entrepreneurial start-ups in a developing country. Entrepreneurship and Regional Development, 20(March), 111-124.

Odusegun, E. (2014.) Youth leader blames corruption for youth unemployment. Vanguard News. [Online] Available: http://www.vanguardngr.com. (25 June 2014).

Oladele, P.O., Akeke, N.I. \& Oladunjoye, O. (2011). Entrepreneurship development: A panacea for unemployment in Nigeria. Journal of Emerging Trends in Economics and Management Sciences, 2(4), 254-256.

Raguž, I.V. \& Matić, M. (2011). Student's perceptions and intentions towards entrepreneurship: The empirical findings from the University of Dubrovnik-Croatia. International Journal of Management Cases, Special issue: Circle Conference, 38-49.

Remeikienè, R. \& Startienè, G. (2013). Do business promotion programmes raise human capital? The case of Lithuania. Business Management Dynamics, 2(10), 06-13.

Solomon, G.T., Duffy, S. \& Tarabishy, A. (2002).The State of Entrepreneurship Education in the United States: a Nationwide Survey and Analysis. International Journal of Entrepreneurship Education, 1(1), 65-86.

Statistics South Africa. (2011). Mid-year population estimates. July 2011. Pretoria: Government Printer.

Statistics South Africa. (2013a). Quarterly employment statistics. June 2013. Pretoria: Government Printer.

Statistics South Africa. (2013b). Mid-year population estimates. May 2013. Pretoria: Government Printer. 
StatsSA see Statistics South Africa.

Stutz, F.P. \& Warf, B. (2012). The World Economy. Geography, Business, Development. 6th Edition. New Jersey: Prentice Hall.

Synodinos, N.E. (2003) The "art" of questionnaire construction: some important considerations for manufacturing studies, Integrated Manufacturing Systems, 14(3), $221-237$.

Taylor, S., Van der Berg, S. \& Burger, R. (2014). Low quality education as a poverty trap in South Africa. [Online] Available: http://www.psppd.org.za/MediaLib/Downloads

/Home/ResearchEvidence/Low\%20quality\%20education\%20as\%20a\%20poverty\% 20trap\%20in\%20South\%20Africa.pdf. (25 June 2014).

Tkachev, A. \& Kolvereid, L. (1999). Self employment intentions among Russion students. Entrepreneurship and Regional Development, $11(3), 269-280$

Uddin, P.S.O. \& Uddin, O.O. (2013). Causes, effects and solutions to youth unemployment problems in Nigeria. Journal of Emerging Trends in Economics and Management Sciences, 4(4), 397-402.

UN see United Nations.

United Nations (UN). (2003). Human development report, 2003 - Millennium Development Goals: A Compact amongst Nations to End Human Poverty. New York: Oxford University Press.

Venesaar, U., Ling, H. and Voolaid, K. (2011). Evaluation of the entrepreneurship education programme in university: A new approach. The Knowledge Based Economy: Implications for Higher Education in Economics and Business, XIII(30), 377-390.

Wennekers, A., Uhulaner, L. \& Thurik, R. (2002). Entrepreneurship and its conditions: a macro perspective. International Journal of Entrepreneurship Education, 1, 25-64.

Wilkinson, K. (2014). Is SA's education system the worst in Africa? Not according to data. [Online] Available: http://africacheck.org/reports/is-sas-education-system-the-worst-in-africa-not-according-to-the-data/. (25 June 2014). 